\title{
OPTIMIZATION OF MUNICIPAL WASTE MANAGEMENT IN LIBYA
}

\author{
Ibrahim Badi ${ }^{1}$, Željko Stević $^{2}$, Ali Abdulshahed ${ }^{1}$, Živko Erceg ${ }^{2}$ \\ ${ }^{1}$ Misurata University, Libya \\ ${ }^{2}$ University of East Sarajevo, Bosnia and Herzegovina
}

\begin{abstract}
As in many developing countries, Libya is still managing the solid waste improperly. This fact has led to increase the amount of solid wastes accumulated in the country. With low fuel costs, the companies make low consideration to the transportation cost. The research in municipal solid waste in Libya is rare and focused on waste classification area. The objective of this paper is to evaluate the municipal solid waste management system in Misurata city, Libya, and to suggest a model which minimizes the total cost of waste management by adding a collection stations. The paper evalutes two models: in the first model only collection vehicles are used, and the waste transfered directly to the dumping site. In the second model collection sites are tested, and the best one is selected according to the total cost. ADD algorithm used in the second model. The second model showed that there is a reduction in the total distance travelled by the trucks up to $45 \%$.
\end{abstract}

Key words: Municipal solid waste, Libya, collection station, ADD algorithm.

\section{Introduction*}

In developing countries, the urbanisation increased concentration of people which implies an accumulation of waste that needs to be properly disposed. Developing an adequate plan for waste management in these countries is still a real challenge. Recent studies have shown that the selection of an adequate solid waste management (SWM) strategy in underdeveloped and developing countries contributes to its optimization [1]. The implementation of the so-called 3R strategy (which are reduce, reuse and recycle) is growing, as it is necessary to reduce the wastes at the place of production, then to reuse it, and the last option is to recycle [2].

Unsuitable waste management practices may cause degradation of valuable land resources and create long-term environmental and human health problems. An efficient waste management plan is needed to obtain the quality of life and environment. Waste management requires many emerging technologies related to waste generation, collection and classification, transportation, and final disposal.

Awareness to waste can affect all stages in the waste management process [3]. This has an impact on all waste management systems include: waste segregation, recycling, collection, willingness to pay for services, and the level and type of opposition to waste remedy and disposal services [4].

Waste collection stations play a significant role in a resident's total waste management system, serving as the link between a resident's waste collection schedule and a final disposal site. [5]. Badran and El-Haggar used mixed integer programming to find the best locations of the collection sites in Port Said [6]. Pérez-Salazar et al. [7] used a mixed integer programming model for facility location from pre-identified locations in Mexico. Asase et

(c) Badi I., Stević Ž., Abdulshahed A., Erceg Ž., 2018. al. [8] reviewed the integrated waste management systems in the city of London, Ontario-Canada and Kumasi, Ghana. Das and Bhattachayya [9] used mixed integer programming and heuristic algorithm to optimize the collection and routing in the waste management system to minimize the total cost. Economic considerations play an important role when the waste is to be transported at a distant site [10]. Kirca et al. [11] introduced that a integer model for determining the best locations of the collection stations. The model developed is a location-allocation model where the objective function training to optain a minimum cost tradeoff between the sum of fixed and operating costs of the collection stations. [12] used a model which determines the optimal locations of the landfill sites as well as the locations of the collection stations in North Greece. They implement a number of models to a number of district problems. In their approach described, various population growth patterns are considered, and multi-period decisions are made. However, most of the above-mentioned studies for the collection station problem try to identify the optimal location and number of collection stations for a given waste management task. Novarlić et al. Suggested innovative way of transport in organizing transport routes to improve waste management in cities [13].

Undoubtedly, sizes, and services offered very important for collection stations; they all serve the same basic goal (transfer waste from a number of collection vehicles into larger vehicles for more economical service to dumping sites. In this form, a collection station is used to receive waste in the areas which designed to receive waste from small vehicles. The waste is normally compacted, then loaded into larger vehicles (e.g., usually transfer trailers, containers, railcars, and barges). On the other hand, longhaul were shipment to a final site; typically, a landfill, damping sites or a composting facility. No long-term storage of waste takes place at a collection station; waste is quickly combined and loaded into a larger vehicle and 
transferred, usually in a short period.

Depending on its characteristics, the MSW can be preferentially processed by different approaches. The present waste management methods in Libya are highly dependent on dumping sites as only 3\% of the MSW is recycled and composted, while the remaining $97 \%$ of MSW is eliminated through open dumping sites [14]. Waste recycling is mainly performed by garbage scavengers at the dumping sites. To date, SWM in Libya is at the stage of transition and planning towards sustainable and effective approaches. Sustainable and more efficient waste management strategies are needed to reduce the heavy reliance on dumping sites.

Rapid urbanisation, population growth and industrialisation contribute towards a large-scale increase of MSW in Libya. These factors have changed the characteristics and composition of the solid waste generated. For instance, the majority of the residents in the central part of Libya are dissatisfied with the current existing solid waste management program, and the current SWM services are inefficient [15].

It is found that optimization of solid waste management has not yet been used in any of the Libyan cities. All research regarding municipal solid waste in Libya conducted in the field of waste classification [16-19].

\section{Municipal waste in Misurata city}

The waste management system in Misurata city, as the other Libyan cities, led to piling up of mountains of waste in the different sites. The waste accumulated even in the streets (see figure 1). The City Council (CC) controls the whole system of the MSW, starting from the collection, transportation process, and ending by damping sites. Furthermore, the $\mathrm{CC}$ has some equipment and the infrastructures such as trucks and final dumping site. Currently, and for many years, these services provided freely. Like the other Libyan cities, waste is mostly dumped in the damping sites and burned it in open areas [20]. Consequently, the resulting pollutions can cause much health and environmentally problems. The processes of collection and disposal of the waste are the responsibility of the $\mathrm{CC}$ which has limited equipment, and therefore, provide unreliable services. When the dumping sites are filled with wastes, the only solution for $\mathrm{CC}$ is to burn it. This inappropriate management of wastes can lead to serious health and environmental problems as a result of fires, explosions, and contamination of air, and might affect water as well. Undoubtedly, wastes polluting the environment and threaten human health requires the public education and awareness.

The quantity of MSW generated in Misurata is estimated to be more than 400 tons/day. About $85 \%$ of the produced waste is throwing in open dumps and about $(15 \%)$ is composted. Even some of the waste is burned in the open areas, there are more than 2.300 open dumps in the country with an area of approximately 3.500 ha [14]. Most of these dumps are nearly saturated and no monitoring nor evaluation procedure to the MSW activities. Therefore, there is almost no performance or target that should be achieved by the MSW management.

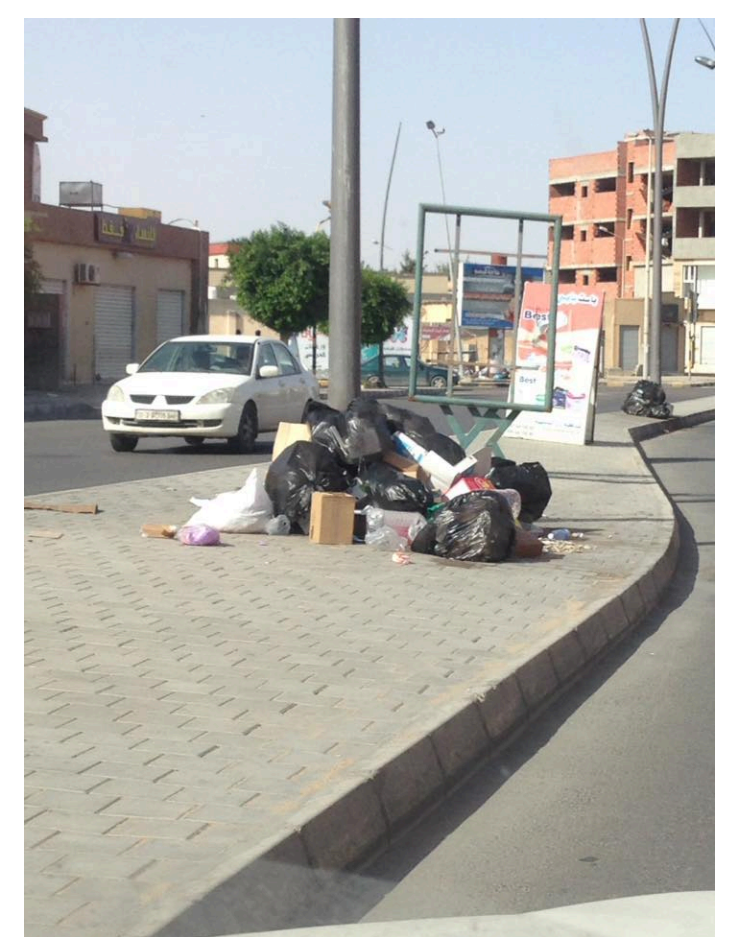

Fig. 1. An overview of the waste accomulates in the street

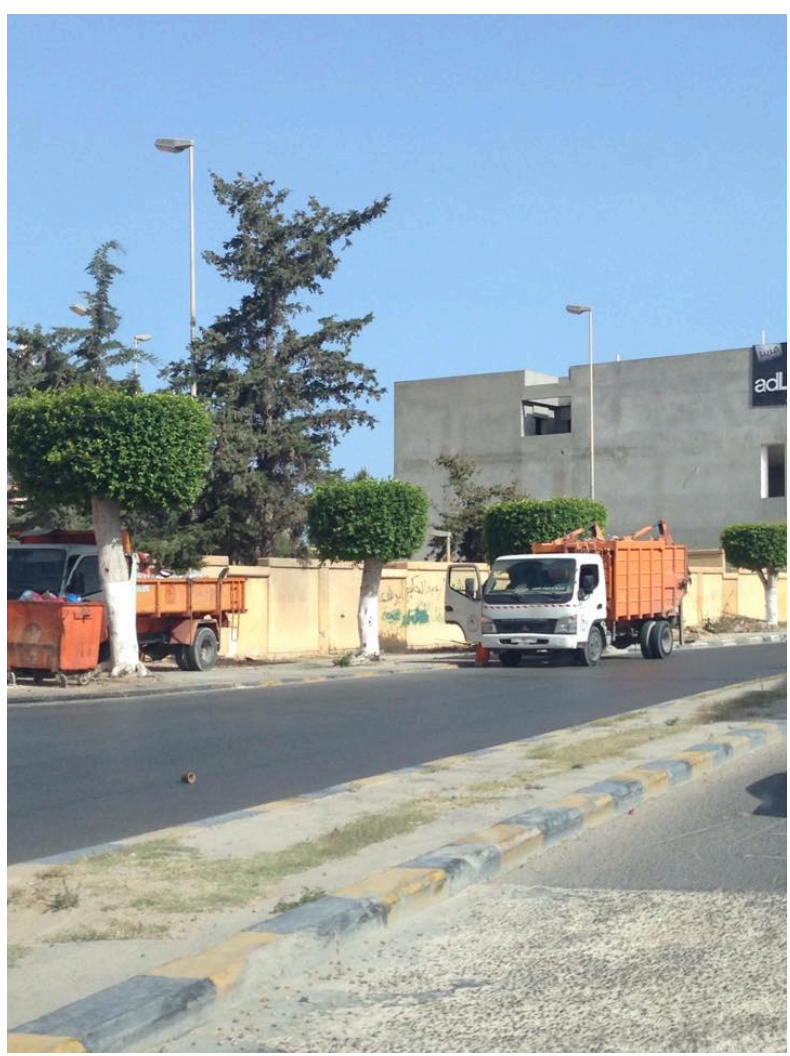

Fig. 2. Collection vehicles used in the area of study

Except the composting plant, there is no treatment provided to the waste after collection. The old trucks used, shortage of technical skills, improper bin collection, and route planning are among the issues resulting in poor 
collection and transportation of MSW. There are different types of vehicles used to collect the wastes such as ordinary trucks, tractor-trailers, dumper-placers, and tippers. The commonly used vehicle is the open-body trucks of 1-5tonne capacity. Tractor-trailers are used in smaller areas even if they were noisy and inefficient. Figure 2 shows a collection vehicle used in the area of study.

In most of Libyan cities, citizens who handle wastes are valued as dirty, and poor, and carrying household waste to bins is often considered as a duty for young people and children. Efforts have been made by Misurata Council to increase public awareness of Waste Management issues, and there have been radio programs on the awareness and education of Waste Management issues. The side effects of inappropriate waste disposal have been well publicised. Nevertheless, most people still do not realize that environmental quality is not just the responsibility of the $\mathrm{CC}$ and that the individual also has an important role.

Collection vehicles consist of pick-up trucks of 1-ton capacity, some of them have a feature of lifting bins. These trucks used for collecting and transferring the waste from the streets to the dumping site. There are also trucks used for the transfer of the construction and demolition waste from sites to the dumping site. A 5-ton flatbed transfer vehicles can be used for waste transfer from the collection stations to the dumping site.

There were two open collection sites in Misurata, and both of them were closed because of people unacceptance. The residents have voiced concerns about waste collection centers who are poorly designed, located, or operated. Moreover, some individuals might feel that collection stations are disproportionately concentrated in or near their communities. Even so, collection stations play a most important role in a local community's waste management system. In this work, two scenarios of waste collection were explained. The goal of this work is to assist the use of best practices in collection station siting to maximize facilities' effectiveness and efficiency, while minimizing their cost and impact on the community.

\section{The approach}

A location problem is to find the locations of facilities, which minimize the sum of weighted Euclidean distances of customers form these locations [21]. Some features should be considered in this approach such as space, number of new facilities to be located, and the number of existing facilities.

Jacobsen [22] generalized incapacitated plant location model to the capacitated model with the lower bound named ADD-LO and the upper bound which named as ADD-HI. Domschke and Drexl [23] also used the same bounds, but with a starting procedure for the initial solution. Akinc and Khumawala [24] used the same branch and bound solution model for capacitated warehouse location problem. The efficient branch and bound solution is made by developing dominance of lower and upper bounding procedures and branch and node selection rules utilizing the special structure of the problem.

In ADD procedure, each depot is added to the solution reduces the cost as much as possible. In each iteration, a depot is greedily added to the solution until the algorithm is not able to find a depot where the largest saving obtains.

The city considered in this case study is Misurata city in Libya (see figure 3). Misurata is the third most populated city in Libya with a population over 300000; Table 1 shows the population of each district in the city. However, a highly dense population results in large quantities of waste production in a small region. Currently, the average daily waste per person was estimated to be over one kilogram. The content of the waste shows some variability during different seasons. As mentioned earlier in this paper, there is no collection stations operating, thus the collection vehicles transport the waste to dumping site, which is at least 40 kilometres away from the city centre.

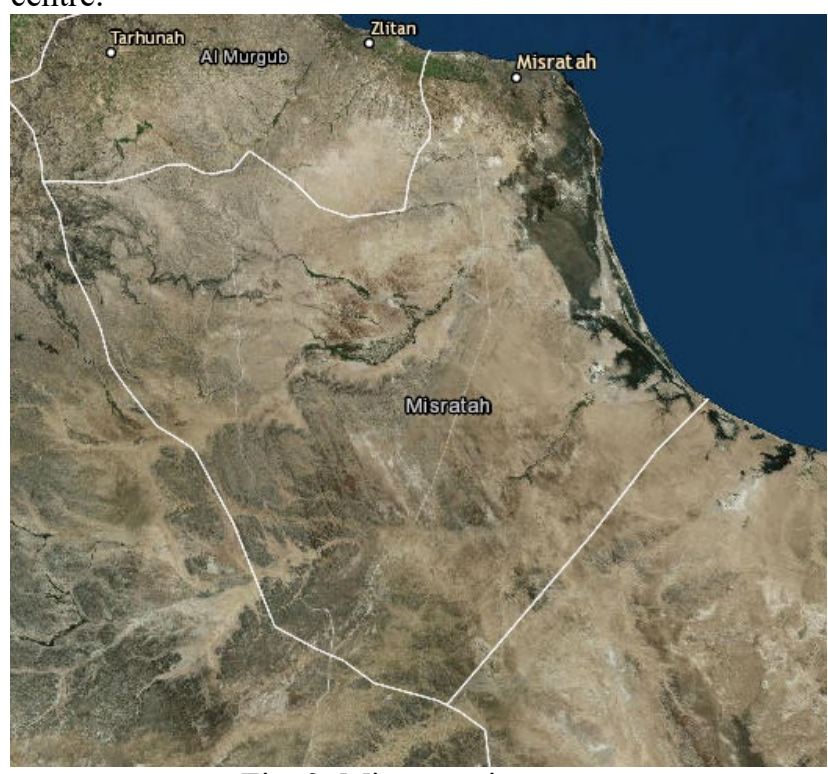

Fig. 3. Misurata city map

Table 1

Population of the districts

\begin{tabular}{clc}
\hline № & \multicolumn{1}{c}{ District } & Population \\
\hline 1 & Tomina & 24.148 \\
2 & Eldafnia & 16.370 \\
3 & Gaser Ahmed & 19.208 \\
4 & Elzaroug & 32.288 \\
5 & Elgiran & 32.924 \\
6 & 9 yolyo & 41.179 \\
7 & Ras Touba & 29.500 \\
8 & Elmahgoub & 30.027 \\
9 & That Elremal & 37.531 \\
10 & Shuhada Rmila & 52.326 \\
\hline & Total population
\end{tabular}

The resources used for collection and transport, trucks and labor, can be utilized more effectively if waste could be transported to dumping site via collection stations. The quantity of waste generated has been significant raised in both quantity and diversity without investment in collection, transport, treatment and disposal services. These difficulties are further involved by political, economic and social influences. The intent of this section is to reduce the cost of transporting waste to the disposal site. Figure $\mathbf{4}$ shows the total quantity of waste generated every day in each district in Misurata city. 


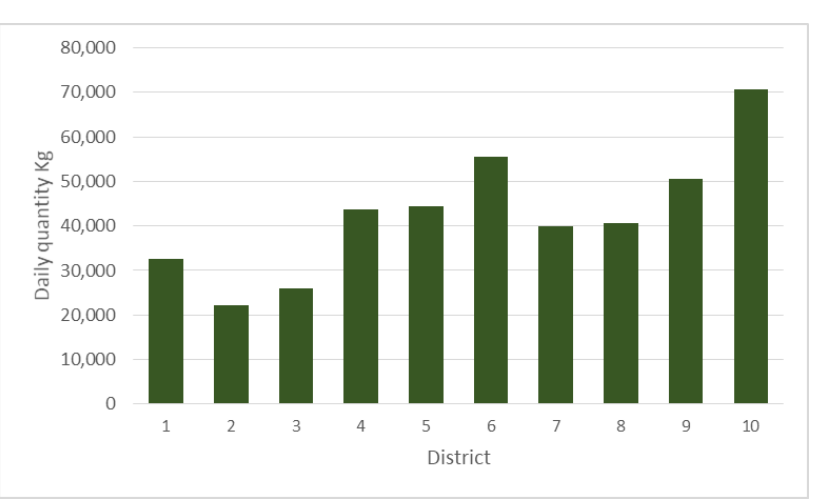

Fig. 4. Total daily waste

Collection and transportation are a major cost in the waste management process [25]. Public firms collect house-to-house, typically between one and two times a week, depending on the availability and condition of their vehicles. Figure 5 shows the total monthly trips per district, which equal to 2.130 trips. These trips are done by small and medium collection vehicles.

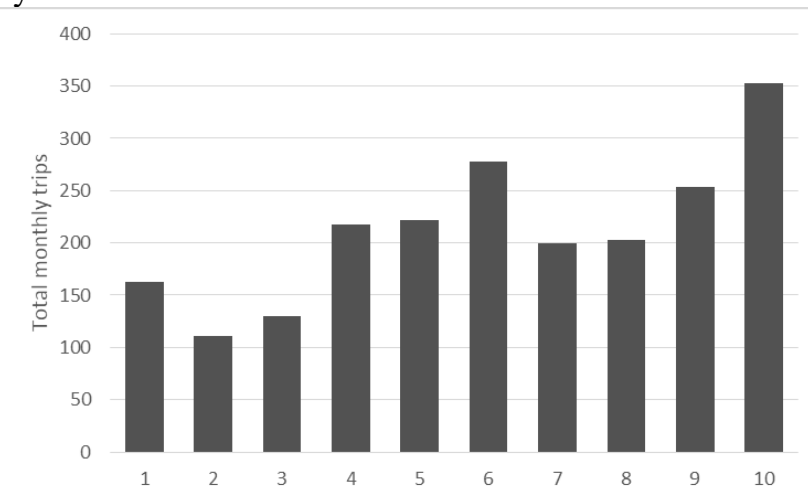

Fig. 5. Total number of trips

The goal of this research is to minimize the total cost. For this purpose, two scenarios of waste collection are illustrated. The different transport models present the different transport approach among following points: With respect to the location problem under consideration, the method is performed in the following steps:

- 10 collection districts;

- one or more collection stations;

- one dumping site.

Figure 6 illustrates both scenarios: First scenario is to send the collected waste directly to the dumping site, which is the current situation. The second scenario is to open collection stations.

\subsubsection{First model}

In this model, only the collection vehicles are used to collect the waste. The transport to the dumping site takes place immediately after the waste collection. Because of the long distances between the collection areas and the dumping site, this approach may be not useful.

In this model, the following steps are taken:

- the first step is to transport from thier parking place to the collection area, and in this step they are empty;
- after collecting the wastes, transport from the collection area to the dumping site with loaded driving;

- transport from the dumping site back to the parcking place after unloading waste.
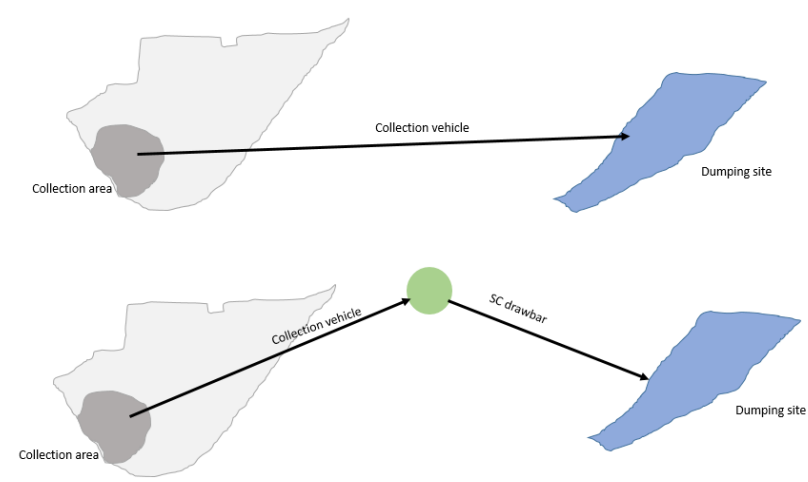

Fig. 6. Current situation and the suggested model

\subsubsection{Second model}

This model is decomposed into two phases. The first phase is the waste collection with the collection vehicles. The second phase is waste transportation with flatbed or SC-drawbar vehicles. There are basically the following routes.

For collection vehicles:

- transport from the parcking place to the collection area;

- transport from the collection area to the collection station;

- after unloading the filled container in the collection station, driving back to the parcking place.

For transfer vehicles:

- transport from the parcking place to the collection station;

- after loading the wastes, transport from the collection statio to the dumping;

- transport from the dumping site back to the parcking place. rithm:

The following notations will be used in ADD algo-

$I=$ the set of locations;

$I_{0}=$ subset of $\mathrm{I}$ that has been decided to close;

$I_{I}=$ subset of $I$ that has been decided to open;

$I_{2}=$ subset of $I$ that is yet undecided.

Anew facility is added at the location which results in the largest saving as follows:

- Calculate the total cost according to the following equation:

Total cost $C_{t}=$ Fixed cost $C_{F}+$ total transportation costs from the collection areas to the collection station $C_{C T}+$ total transportation cost from collection station to the dumping site $C_{T L}$.

- For each depot $(i)$ that belongs to the candidates depots $\left(I_{2}\right)$ or $i \in I_{2}$ computes the saving cost $\left(A_{i 0}\right)$ with the formula below:

$$
A_{i 0}=C^{*}\left(I_{l}, J\right)-C^{*}\left(I_{l} \cup\left\{i_{0}\right\}, J\right)-a_{i 0} .
$$


- find the depot that have the largest saving depot $i$ ( $i *$ such that $A_{i} *=\max i \in I_{2}\left\{A_{i 0}\right\}$ ).

- if $A_{i}{ }^{*}>0, \mathrm{i}^{*}$ is transferred from $I_{2}$ to $I_{1}$ and another iteration is made. If $A_{i} * \leq 0$, the elements of $I_{2}$ are transferred to $I_{0}$.

- When the savings cost is less than zero the computations are discontinued.

At the iteration number one of the first scenario, which shown in figure 7 , it is cleary that opening collection station at any of the sites will minimize the cost
District number 7 is the one with the biggest savings, ans will minimize the total cost by $40 \%$ (to 2235840 ).

Considering that collection station at site number 7 is obened, figure 8 showed the result of iterarion number two. Opening another collection station at district number 2 will decrease the totatl cost to 2192929.

At iteration number three, no savings is occurred and opening new collection station at any district will increase the total cost.

\begin{tabular}{|c|c|c|c|c|c|c|c|c|c|c|}
\hline District \# & 1 & 2 & 3 & 4 & 5 & 6 & 7 & 8 & 9 & 10 \\
\hline Fixed Cost & 192,000 & 252,000 & 252,000 & 276,000 & 300,000 & 240,000 & 294,000 & 432,000 & 396,000 & 420,000 \\
\hline 1 & 0 & 144,000 & 90,000 & 75,600 & 183,600 & 198,000 & 134,400 & 172,800 & 144,000 & 218,400 \\
\hline 2 & 144,000 & 0 & 222,000 & 313,200 & 183,600 & 211,200 & 134,400 & 134,400 & 156,000 & 235,200 \\
\hline 3 & 90,000 & 222,000 & 0 & 399,600 & 345,600 & 224,400 & 182,400 & 268,800 & 192,000 & 302,400 \\
\hline 4 & 75,600 & 313,200 & 399,600 & 0 & 334,800 & 211,200 & 172,800 & 220,800 & 168,000 & 252,000 \\
\hline 5 & 183,600 & 183,600 & 345,600 & 334,800 & 0 & 382,800 & 249,600 & 220,800 & 312,000 & 386,400 \\
\hline 6 & 198,000 & 211,200 & 224,400 & 211,200 & 382,800 & 0 & 57,600 & 105,600 & 60,000 & 117,600 \\
\hline 7 & 134,400 & 134,400 & 182,400 & 172,800 & 249,600 & 57,600 & 0 & 96,000 & 48,000 & 84,000 \\
\hline 8 & 172,800 & 134,400 & 268,800 & 220,800 & 220,800 & 105,600 & 96,000 & 0 & 120,000 & 151,200 \\
\hline 9 & 144,000 & 156,000 & 192,000 & 168,000 & 312,000 & 60,000 & 48,000 & 120,000 & 0 & 67,200 \\
\hline 10 & 218,400 & 235,200 & 302,400 & 252,000 & 386,400 & 117,600 & 84,000 & 151,200 & 67,200 & $\underline{0}$ \\
\hline \multirow{2}{*}{ Cost } & $1,552,800$ & $1,986,000$ & $2,479,200$ & \begin{tabular}{|l|}
$2,424,000$ \\
\end{tabular} & $2,899,200$ & $1,808,400$ & $1,453,200$ & $1,922,400$ & $1,663,200$ & $2,234,400$ \\
\hline & $2,399,329$ & $2,992,251$ & $3,213,923$ & $3,094,834$ & $3,522,117$ & $2,622,984$ & $2,235,840$ & $2,784,901$ & $2,397,923$ & $3,001,067$ \\
\hline
\end{tabular}

Fig. 7. Iteration number 1

\begin{tabular}{|c|c|c|c|c|c|c|c|c|c|c|}
\hline District \# & 1 & 2 & 3 & 4 & 5 & 6 & 7 & 8 & 9 & 10 \\
\hline Fixed Cost & 192,000 & 252,000 & 252,000 & 276,000 & 300,000 & 240,000 & 294,000 & 432,000 & 396,000 & 420,000 \\
\hline 1 & 0 & 144,000 & 90,000 & 75,600 & 144,000 & 144,000 & 134,400 & 144,000 & 144,000 & 144,000 \\
\hline 2 & 144,000 & 0 & 156,000 & 156,000 & 156,000 & 156,000 & 134,400 & 134,400 & 156,000 & 156,000 \\
\hline 3 & 90,000 & 192,000 & 0 & 192,000 & 192,000 & 192,000 & 182,400 & 192,000 & 192,000 & 192,000 \\
\hline 4 & 75,600 & 168,000 & 168,000 & 0 & 168,000 & 168,000 & 168,000 & 168,000 & 168,000 & 168,000 \\
\hline 5 & 183,600 & 183,600 & 312,000 & 312,000 & 0 & 312,000 & 249,600 & 220,800 & 312,000 & 312,000 \\
\hline 6 & 60,000 & 60,000 & 60,000 & 60,000 & 60,000 & 0 & 57,600 & 60,000 & 60,000 & 60,000 \\
\hline 7 & 0 & 0 & 0 & 0 & 0 & 0 & 0 & 0 & 0 & 0 \\
\hline 8 & 120,000 & 120,000 & 120,000 & 120,000 & 120,000 & 105,600 & 96,000 & 0 & 120,000 & 120,000 \\
\hline 9 & 120,000 & 120,000 & 120,000 & 120,000 & 120,000 & 60,000 & 48,000 & 120,000 & 0 & 67,200 \\
\hline 10 & 67,200 & 67,200 & 67,200 & 67,200 & 67,200 & 67,200 & 67,200 & 67,200 & 67,200 & 0 \\
\hline \multirow[t]{2}{*}{ Cost } & $1,346,400$ & & $1,639,200^{\prime}$ & - & 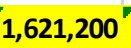 & 60001 & & 832,400 & & ,933,200 \\
\hline & $2,192,929$ & $2,607,051$ & $2,373,923$ & $2,343,634$ & $2,244,117$ & $2,553,384$ & $2,508,240$ & 2,694,901 & $2,643,923$ & 699,867 \\
\hline
\end{tabular}

Fig. 8. Iteration number 2

\begin{tabular}{|c|c|c|c|c|c|c|c|c|c|c|}
\hline District \# & 1 & 2 & 3 & 4 & 5 & 6 & 7 & 8 & 9 & 10 \\
\hline Fixed Cost & 192,000 & 252,000 & 252,000 & 276,000 & 300,000 & 240,000 & 294,000 & 432,000 & 396,000 & 420,000 \\
\hline 1 & 0 & 0 & 0 & 0 & 0 & 0 & 0 & 0 & 0 & 0 \\
\hline 2 & 134,400 & 0 & 134,400 & 134,400 & 134,400 & 134,400 & 134,400 & 134,400 & 134,400 & 134,400 \\
\hline 3 & 90,000 & 182,400 & 0 & 182,400 & 182,400 & 182,400 & 182,400 & 182,400 & 182,400 & 182,400 \\
\hline 4 & 75,600 & 168,000 & 168,000 & 0 & 168,000 & 168,000 & 168,000 & 168,000 & 168,000 & 168,000 \\
\hline 5 & 183,600 & 183,600 & 249,600 & 249,600 & 0 & 249,600 & 249,600 & 220,800 & 249,600 & 249,600 \\
\hline 6 & 57,600 & 57,600 & 57,600 & 57,600 & 57,600 & 0 & 57,600 & 57,600 & 57,600 & 57,600 \\
\hline 7 & 0 & 0 & 0 & 0 & 0 & 0 & 0 & 0 & 0 & 0 \\
\hline 8 & 96,000 & 96,000 & 96,000 & 96,000 & 96,000 & 96,000 & 96,000 & 0 & 96,000 & 96,000 \\
\hline 9 & 120,000 & 120,000 & 120,000 & 120,000 & 120,000 & 60,000 & 48,000 & 120,000 & 0 & 67,200 \\
\hline 10 & 67,200 & 67,200 & 67,200 & 67,200 & 67,200 & 67,200 & 67,200 & 67,200 & 67,200 & 0 \\
\hline \multirow[t]{2}{*}{ Cost } & $1,502,400$ & 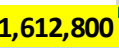 & 900001 & $\operatorname{sco} 200$ & $1,611,600$ & $1,683,600$ & $1,783,200$ & $1,868,400$ & $1,837,200$ & $.861,200$ \\
\hline & $2,348,929$ & $2,619,051$ & $2,365,523$ & $2,340,034$ & $2,234,517$ & $2,498,184$ & $2,565,840$ & $2,730,901$ & $2,571,923$ & $2,627,867$ \\
\hline
\end{tabular}

Fig. 9. Iteration number 3 
Figure 10 shows the results for different scenarios. For first scenario, the total cost for one year equals to 3703 324. This cost could be reduced by adding two collection stations at disrticts 7 and district 1 .

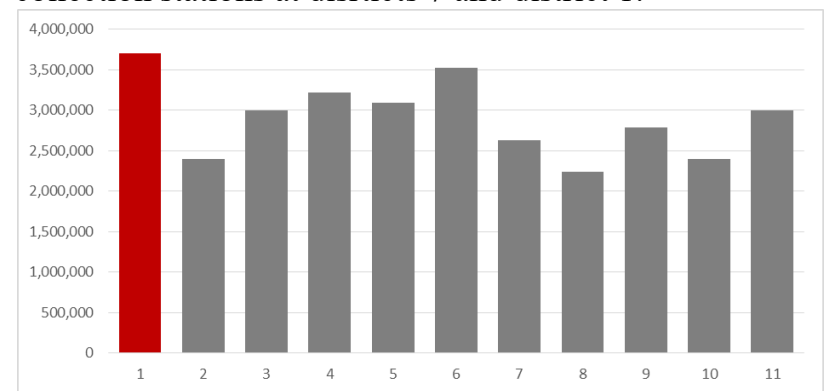

Fig. 10. Results of both scenarios

The primary purpose for using collection stations is to minimize the transportation cost to the damping sites. Integrating a small amount of waste from collection vehicles into larger vehicles will minimize the cost of transporting of waste by allowing staffs to spend less time carrying of waste to damping sites and more time collecting waste. Furthermore, this procedure also will reduce vehicle maintenance costs and fuel consumption, while minimizing the overall traffic in the city center. In addition, a collection station also may provide: A possibility to classify the waste prior to disposal; An opportunity to select the optimal disposal options; A possibility to service as a collection centre for public use.

At the collection center, workers can classify coming wastes to different categories. Waste classification has two stages: separating recyclables waste and identifying any parts that might be unsuitable for disposal (e.g., harmful wastes, white goods, material, tires, or batteries). Distinguishing and extracting recyclable items (which might generate revenue) reduces the volume and weight of waste transporting to the final damping sites. Classifying and removing inappropriate wastes might be more efficient in the collection centers than the damping sites.

Waste collection centers also might offer adaptability in terms of disposal alternatives. $\mathrm{CC}$ decision-makers will have great opportunity to choose the most effective option for damping sites, even with the cost of more distant. Moreover, they also can think about multiple damping sites, secure competitive transporting fees, and select a desired method at damping site.

As abovementioned, collection centers can open to public use. For instance, this facility enables residents to transfer waste directly to the local collection center for classification and later for final disposal. Some collection centers might offer service to collect bulky items, yard items, hazardous, and recyclable items. These centers can be also used to help the residents because they facilitate in achieving recycling objectives and increase the public's awareness of proper waste Management.

\section{Conclusions}

Waste management is a global and challenging environmental issue facing the world. This paper illustrates the current situation of waste collection, management, transportation, and final disposal in Misurata, Libya. The performance of the MSW system depends heavily on many important factors such as the country situation, policies in environmental fields, the available technology, and the awareness and education of residents. Increased community awareness is needed by Misurata city council regarding waste management issues.

One of the objectives of this work is to suggest optimal locations and an investment plan for collection stations to the Municipal Council of Misurata. Two models have been evaluated in order to help the decision maker to prepare a request for a proposal for a collection station bidding, by determining the total number of the collection stations. The waste management system in Misurata city suffers from many factors includes technical issues, unfavorable legislative, and operational constraints. More active responsibility of the private sector and full integration of the unofficial sector is suggested.

\section{References}

1. Coban A., Ertis I. F., Cavdaroglu N. A. Municipal solid waste management via multi-criteria decision making methods // Journal of Cleaner Production. 2018, vol. 180, pp. 159-167. doi: 10.1016/j.jclepro.2018.01.130.

2. Ma J., Hipel K. W. Exploring social dimensions of municipal solid waste management around the globe - A systematic literature review // Waste management (New York, N.Y.). 2016, vol. 56, pp. 3-12. doi: 10.1016/j.wasman.2016.06.041.

3. Zurbrügg C. Urban solid waste management in low-income countries of Asia - how to cope with the garbage crisis // Urban Solid Waste Management Review Session. 2002, Durban: Scientific Committee on Problems of the Environment (SCOPE), pp. 1-13.

4. Imam A., Mohammed B., Wilson D.C., Cheeseman C.R. Solid waste management in Abuja, Nigeria // Waste management (New York, N.Y.). 2008, vol. 28, no. 2, pp. 468-472. doi: 10.1016/j.wasman.2007.01.006.

5. Visvanathan C., Tränkler J. Municipal solid waste management in Asia: A comparative analysis // Workshop on Sustainable Landfill Management 35 December. 2003, Chennai, India, pp. 3-15.

6. Badran M.F., El-Haggar S.M. Optimization of municipal solid waste management in Port Said - Egypt // Waste management (New York, N.Y.). 2006, vol. 26, no. 5, pp. 534-545. doi: 10.1016/i.wasman.2005.05.005.

7. María del Rosario Pérez-Salazar, Nicolás Francisco Mateo-Díaz, Rogelio García Rodríguez, Lidilia Cruz Rivero, Carlos Eusebio Mar Orozco. A mixed integer model of the capacitated facility location problem for solid waste management at the northern region of Veracruz, Mexico // Recent Advances in Theory, Methods, and Practice of Operations Research. 2014, Monterrey: UANL - Casa Universitaria del Libro, pp. 113-120.

8. Asase M., Yanful E. K., Mensah M., Stanford J., Amponsah S. Comparison of municipal solid waste management systems in Canada and Ghana: A case study of the cities of London, Ontario, and Kumasi, Ghana // Waste Management. 2009, vol. 29, no. 10, pp. 2779-2786. doi:10.1016/j.wasman.2009.06.019.

9. Das S., Bhattacharyya B. K. Optimization of municipal solid waste collection and transportation routes // Waste management (New York, N.Y.). 2015, vol. 43, pp. 9-18. doi: 10.1016/j.wasman.2015.06.033.

10. Kharat M. G., Kamble S. J., Raut R. D., Kamble S. S., Dhume S. M. Modeling landfill site selection using an integrated fuzzy MCDM approach // Modeling Earth Systems and Environment. 2016, vol. 2, no. 2, p. 758. doi: 10.1007/s40808-016-0106-x.

11. Kirca Ö., Erkip N. Selecting transfer station locations for large solid waste systems // European Journal of Operational Research. 1988, vol. 35, no. 3, pp. 339-349. doi: 10.1016/0377-2217(88)90224-X.

12. Erkut E., Karagiannidis A., Perkoulidis G., Tjandra S. A. A multicriteria facility location model for municipal solid waste management in North Greece // European Journal of Operational Research. 2008, vol. 187, no.3, pp. 1402-1421. doi: 10.1016/j.ejor.2006.09.021.

13. Boris Novarlić, Željko Stević, Predrag Đurić, Marko Vasiljević Efficiency in organizing transport routes as part of the city waste management: proposal for innovative way of transport // International Journal for Quality Research. 2017, vol. 11, no. 3. doi: 10.18421/IJQR11.03-02.

14. Hamad T. A., Agll A. A., Hamad Y. M., Sheffield J. W. Solid waste as renewable source of energy: current and future possibility in Libya // Case Studies in Thermal Engineering. 2014, vol. 4, pp. 144-152. doi:10.1016/j.csite.2014.09.004

15. Omran A., Gebril A.O. Municipal solid waste management practices in the central part of Libya // The Impact of Climate Change on Our Life: The Questions of Sustainability. 2018, Singapore: Springer Singapore, pp.149- 
165.

16. Abdelnaser O., ALsadey S., Gavrilevscu M. Municipal solid waste management in Bani Walid City, Libya // Journal of Environmental Management and Tourism. 2011, vol. 2, no. 2.

17. Naser Ali Ahmed Alhderi, Purwanto Purwanto, Henna Rya Sunoko Impacts of four seasons in municipal solid waste in Al-Khums City // Science Journal of Environmental Engineering Research. 2015, vol. 2015 pp.1-5. doi: 10.7237/sjeer/191.

18. Omran A.G., Gebril A.O., Pakir H.K. Solid waste management in Al-Abyar City, Libya // SGEM2011 11th International Multidisciplinary Scientific GeoConference. 2011, Albena Seaside \& Spa Resort, Bulgaria: Stef92 Technology. vol. 3, pp. 617-622

19. Gebril A. O., Omran A., Pakir A. H. K., Aziz H. A. Municipal solid waste management in Benghazi (Libya) // Environmental Engineering and Management Journal. 2010, vol. 9, no. 9, pp. 1289-1296 doi:10.30638/eemj.2010.167.

20. Omran A., Altawati M., Davis G. Identifying municipal solid waste management opportunities in Al-Bayda City, Libya // Environment, Development and Sustainability. 2018, vol. 20, no. 4, pp. 1597-1613. doi:10.1007/s10668-017-9955-3

21. Srivastava R. Algorithms for solving the location - routing problem: $\mathrm{PhD}$ thesis. Ohio: The Ohio State University. 1986. 269 p.

22. Jacobsen S. K. Heuristics for the capacitated plant location model // European Journal of Operational Research. 1983, vol. 12, no. 3, pp. 253261. doi: 10.1016/0377-2217(83)90195-9.

23. Domschke W., Drexl A. ADD-heuristics' starting procedures for capacitated plant location models // European Journal of Operational Research. 1985, vol. 21, no. 1, pp. 47-53. doi: 10.1016/0377-2217(85)90086-4.

24. Akinc U., Khumawala B. M. An Efficient Branch and Bound Algorithm for the Capacitated Warehouse Location Problem // Management Science. 1977, vol. 23, no. 6, pp. 585-594. doi: 10.1287/mnsc.23.6.585.

25. Sharholy M., Ahmad K., Mahmood G., Trivedi R. C. Municipal solid waste management in Indian cities - A review // Waste management (New York N.Y.). 2008, vol. 28, no. 2, pp. 459-467. doi: 10.1016/j.wasman.2007.02.008

Received 10/09/2018

\section{ДАННЫЕ СТАТЬИ НА РУССКОМ ЯЗЫКЕ}

\title{
ОПТИМИЗАЦИЯ ВЫВОЗА ТВЁРДЫХ БЫТОВЫХ ОТХОДОВ В ЛИВИИ
}

\author{
Бади Ибрагим - доцент, $\mathrm{PhD}$ \\ Университет Мисрата, Ливия. E-mail: ibrahim.badi@hotmail.com \\ Стевич Желько - $\mathrm{PhD}$ \\ Восточно-Сараевский университет, Босния и Герцеговина. E-mail: zeljkostevic88@yahoo.com \\ Абдушахед Али - $\mathrm{PhD}$ \\ Университет Мисрата, Ливия. E-mail: aa_shahed@yahoo.com \\ Эрцег Живко - PhD \\ Восточно-Сараевский университет, Босния и Герцеговина. E-mail: zivkoerceg@gmail.com
}

\begin{abstract}
Аннотация
Управление твёрдыми бытовыми отходами в Ливии, как и во многих развивающихся странах, по-прежнему организовано ненадлежащим образом. В результате несвоевременного вывоза отходов наблюдается их скопление в городах. Одна из причин такого положения заключается в том, что компании, обеспечивающие вывоз мусора, не принимают в расчёт транспортные затраты по причине низкой стоимости топлива. Исследования в области утилизации твёрдых бытовых отходов в Ливии редки и сосредоточены, главным образом, на проблеме сортировки отходов. Целью настоящего исследования является оценка системы управления твёрдыми бытовыми отходами в городе Мисрата (Ливия) и разработка модели, которая позволяет определить минимум суммарных затрат на переработку твёрдых бытовых отходов в результате использования дополнительных пунктов (станций) накопления отходов. В статье представлен анализ двух моделей: в первой модели рассматривается вариант транспортировки твёрдых бытовых отходов непосредственно на место их захоронения; во второй модели оценивается эффективность предварительного накопления отходов на промежуточной станции Критерием эффективности второй модели является величина суммарных затрат на переработку отходов. В качестве расчётного метода используется ADD-алгоритм. Результаты расчётов с использованием предлагаемой модели показали, что сокращение общего пробега автомобилей-мусоровозов, в случае использования промежуточного пункта накопления мусора, может достигать 45\%.
\end{abstract}

Ключевые слова: твёрдые бытовые отходы, Ливия, накопительные пункты, ADD-алгоритм.

\section{Список литературь}

1. Coban A., Ertis I. F., Cavdaroglu N. A. Municipal solid waste management via multi-criteria decision making methods // Journal of Cleaner Production. 2018, vol. 180, pp. 159-167. doi: 10.1016/j.jclepro.2018.01.130.

2. Ma J., Hipel K. W. Exploring social dimensions of municipal solid waste management around the globe - A systematic literature review // Waste management (New York, N.Y.). 2016, vol. 56, pp.3-12. doi: 10.1016/j.wasman.2016.06.041.

3. Zurbrügg $\mathrm{C}$. Urban solid waste management in low-income countries of Asia - how to cope with the garbage crisis // Urban Solid Waste Management Review Session. 2002, Durban: Scientific Committee on Problems of the Environment (SCOPE), pp. 1-13.
4. Imam A., Mohammed B., Wilson D.C., Cheeseman C.R. Solid waste management in Abuja, Nigeria // Waste management (New York, N.Y.). 2008, vol. 28, no. 2, pp. 468-472. doi: 10.1016/j.wasman.2007.01.006.

5. Visvanathan C., Tränkler J. Municipal solid waste management in Asia: A comparative analysis // Workshop on Sustainable Landfill Management 35 December. 2003, Chennai, India, pp. 3-15.

6. Badran M.F., El-Haggar S.M. Optimization of municipal solid waste management in Port Said - Egypt // Waste management (New York, N.Y.). 2006, vol. 26, no. 5, pp. 534-545. doi: 10.1016/j.wasman.2005.05.005.

7. María del Rosario Pérez-Salazar, Nicolás Francisco Mateo-Díaz, Rogelio García Rodríguez, Lidilia Cruz Rivero, Carlos Eusebio Mar Orozco A mixed integer model of the capacitated facility location problem for solid waste management at the northern region of Veracruz, Mexico // Recent Advances in Theory, Methods, and Practice of Operations Research. 2014, Monterrey: UANL - Casa Universitaria del Libro, pp. 113-120.

8. Asase M., Yanful E. K., Mensah M., Stanford J., Amponsah S. Comparison of municipal solid waste management systems in Canada and Ghana: A case study of the cities of London, Ontario, and Kumasi, Ghana // Waste Management. 2009, vol. 29, no. 10, pp. 2779-2786. doi:10.1016/j.wasman.2009.06.019.

9. Das S., Bhattacharyya B. K. Optimization of municipal solid waste collection and transportation routes // Waste management (New York, N.Y.). 2015, vol. 43, pp. 9-18. doi: 10.1016/j.wasman.2015.06.033.

10. Kharat M. G., Kamble S. J., Raut R. D., Kamble S. S., Dhume S. M. Modeling landfill site selection using an integrated fuzzy MCDM approach // Modeling Earth Systems and Environment. 2016, vol. 2, no. 2, p. 758. doi: 10.1007/s40808-016-0106-x.

11. Kirca Ö., Erkip N. Selecting transfer station locations for large solid waste systems // European Journal of Operational Research. 1988, vol. 35, no.3, pp. 339-349. doi: 10.1016/0377-2217(88)90224-X

12. Erkut E., Karagiannidis A., Perkoulidis G., Tjandra S. A. A multicriteria facility location model for municipal solid waste management in North Greece // European Journal of Operational Research. 2008, vol. 187, no.3 pp. 1402-1421. doi: 10.1016/j.ejor.2006.09.021.

13. Boris Novarlić, Željko Stević, Predrag Đurić, Marko Vasiljević Efficiency in organizing transport routes as part of the city waste management: proposal for innovative way of transport // International Journal for Quality Research. 2017, vol. 11, no. 3. doi: 10.18421/IJQR11.03-02.

14. Hamad T. A., Agll A. A., Hamad Y. M., Sheffield J. W. Solid waste as renewable source of energy: current and future possibility in Libya // Case Studies in Thermal Engineering. 2014, vol. 4, pp. 144-152. doi:10.1016/j.csite.2014.09.004.

15. Omran A., Gebril A.O. Municipal solid waste management practices in the central part of Libya // The Impact of Climate Change on Our Life: The Questions of Sustainability. 2018, Singapore: Springer Singapore, pp.149- 
165

16. Abdelnaser O., ALsadey S., Gavrilevscu M. Municipal solid waste management in Bani Walid City, Libya // Journal of Environmental Management and Tourism. 2011, vol. 2, no. 2.

17. Naser Ali Ahmed Alhderi, Purwanto Purwanto, Henna Rya Sunoko Impacts of four seasons in municipal solid waste in Al-Khums City // Science Journal of Environmental Engineering Research. 2015, vol. 2015, pp.1-5. doi: 10.7237/sjeer/191.

18. Omran A.G., Gebril A.O., Pakir H.K. Solid waste management in Al-Abyar City, Libya // SGEM2011 11th International Multidisciplinary Scientific GeoConference. 2011, Albena Seaside \& Spa Resort, Bulgaria: Stef92 Technology. vol. 3, pp. 617-622.

19. Gebril A. O., Omran A., Pakir A. H. K., Aziz H. A. Municipal solid waste management in Benghazi (Libya) // Environmental Engineering and Management Journal. 2010, vol. 9, no. 9, pp. 1289-1296. doi:10.30638/eemj.2010.167.

20. Omran A., Altawati M., Davis G. Identifying municipal solid waste management opportunities in Al-Bayda City, Libya // Environment, Devel- opment and Sustainability. 2018, vol. 20, no. 4, pp. 1597-1613. doi:10.1007/s10668-017-9955-3

21. Srivastava R. Algorithms for solving the location - routing problem: $\mathrm{PhD}$ thesis. Ohio: The Ohio State University. 1986. 269 p.

22. Jacobsen S. K. Heuristics for the capacitated plant location model // European Journal of Operational Research. 1983, vol. 12, no. 3, pp. 253 261. doi: 10.1016/0377-2217(83)90195-9.

23. Domschke W., Drexl A. ADD-heuristics' starting procedures for capacitated plant location models // European Journal of Operational Research. 1985, vol. 21, no. 1, pp. 47-53. doi: 10.1016/0377-2217(85)90086-4.

24. Akinc U., Khumawala B. M. An Efficient Branch and Bound Algorithm for the Capacitated Warehouse Location Problem // Management Science. 1977, vol. 23, no. 6, pp. 585-594. doi: 10.1287/mnsc.23.6.585.

25. Sharholy M., Ahmad K., Mahmood G., Trivedi R. C. Municipal solid waste management in Indian cities - A review // Waste management (New York management in lndian cities - A review $/ /$ Waste management (New York,
N.Y.). 2008, vol. 28, no. 2, pp. 459-467. doi:10.1016/j.wasman.2007.02.008.

Материал поступил в редакцию 10.09.2018

Бади И., Стевич Ж., Абдушахед А., Эрцег Ж. Оптимизация вывоза твёрдых бытовых отходов в Ливии // Современные проблемы транспортного комплекса России. 2018. Т.8. №1. С. 12-19

Badi I., Stević Ž., Abdulshahed A., Erceg Ž. Optimization of municipal waste management in Libya //Sovremennye problemy transportnogo kompleksa Rossii [Modern Problems of Russian Transport Complex]. 2018, vol.8, no.1, pp. 12-19 